\title{
NOTIZEN
}

\section{The Crystal Structure of $\mathrm{TIBrI}_{2}$ (4-methylpyridine-N-oxide)}

W. Hiller*, A. Castiñeiras, and M. E. GarcíaFernandez

Institut für Anorganische Chemie

der Universität Tübingen,

Auf der Morgenstelle 18, D-7400 Tübingen

M. R. Bermejo, J. Bravo, and A. Sanchez

Departamento de Química Inorganíca, Facultad de Química, Universidad, Santiago de Compostela (Spain)

Z. Naturforsch. 43b, 132-133 (1988); received August 22/September 7, 1987

Bromo-diiodo-bis(4-methylpyridine-N-oxide)thallium(III), Crystal Structure, Thallium(III) Halide Compounds

The unit cell of $\mathrm{TlBrI}_{2}$ (4-methylpyridine-N-oxide) is orthorhombic, space group Pnna, with $a=$ 1126.9(3), $b=919.8(2), c=1210.4(3) \mathrm{pm}$, and $Z=4$. The structure consists of discrete $\mathrm{TlBrI}_{2}$ (4-methylpyridine- $\mathrm{N}$-oxide $)_{2}$ molecules which have a distorted trigonal-bipyramidal geometry. The thallium atom is coordinated to two iodine atoms and a bromine atom in equatorial positions, and by two 4-methylpyridine- $\mathrm{N}$-oxide ligands in the axial positions.

\section{Introduction}

Our research on coordination of thallium trihalides with different ligands $[1,2]$ has lately concentrated on the study of the interhalocompounds of thallium(III) of the type $\operatorname{Tl} X X_{2}^{\prime} \cdot \mathrm{n} L(X=$ halide, $L=$ ligand)

Recently we described the crystal structures of $\mathrm{TlBr}_{2} \mathrm{I}\left(\mathrm{OPPh}_{3}\right)_{2}[3]$ and $\mathrm{TlBrI}_{2}\left(\mathrm{OPPh}_{3}\right)_{2}$ [4]. Here, as a continuation of our studies on stabilization of thallium(III) in the complexes indicated above, we report the molecular structure of $\mathrm{TlBrI}_{2}(4-\mathrm{picO})_{2}$ (4-picO = 4-methylpyridine-N-oxide).

\section{Structure Determination}

$\mathrm{TlBrI}_{2}(4-\mathrm{picO})_{2}$ was prepared by oxidation of $\mathrm{TlBr}$ with iodine in acetonitrile in the presence of 4-methylpyridine-N-oxid by the method described by Bermejo et al. [2]. For the structure determination, the data were collected at room temperature using the automated four-circle diffractometer CAD 4 (ENRAF-

\footnotetext{
* Reprint requests to Dr. W. Hiller.

Verlag der Zeitschrift für Naturforschung, D-7400 Tübingen 0932-0776/88/0100-0132/\$ 01.00/0
}

NONIUS, Delft) with graphite-monochromated $\mathrm{MoK}_{a}$ radiation. The cell constants were determined from the setting angles of 25 reflections (Table I) and

Table I. Crystal data for $\mathrm{TlBrI}_{2}(4-\mathrm{PicO})_{2}{ }^{*}$.

\begin{tabular}{ll}
\hline Molecular formula & $\mathrm{C}_{12} \mathrm{H}_{14} \mathrm{BrI}_{2} \mathrm{~N}_{2} \mathrm{O}_{2} \mathrm{Tl}$ \\
Molecular weight & 756.34 \\
Crystal class & Orthorhombic \\
Space group & Pnna $\left(\mathrm{N}^{\circ} 52\right)$ \\
Lattice constants & $a=1126.9(3) \mathrm{pm}$ \\
& $b=919.8(2) \mathrm{pm}$ \\
& $c=1210.4(3) \mathrm{pm}$ \\
Cell volume & $\mathrm{V}=1254.610^{6} \mathrm{pm}^{3}$ \\
Formula units & $Z=4$ \\
Density & $Q_{x}=3.426 \mathrm{~g} \cdot \mathrm{cm}^{-3}$
\end{tabular}

* Further details of the structure determination have been deposited as Supplementary Publication No. CSD 52808. Copies may be obtained through the Fachinformationszentrum Energie, Physik, Mathematik, D-7514 Eggenstein-Leopoldshafen.

from the systematic absences observed, the space group Pnna was determined. With $\omega / \theta$ scan mode, 4539 reflections were collected in the range of $\theta=$ $3-32^{\circ}$. Corrections for Lorentz and polarization effects and an empirical absorption correction ( $\psi$-scan) [5] were applied. From 2084 independent reflections $\left(R_{\text {int }}=0.032\right), 1108$ with $\mathrm{I}>3 \cdot \sigma(\mathrm{I})$ were considered as observed and used for refinement. The structure was solved using the Patterson heavy-atom method, which revealed the positions of the $\mathrm{Tl}$, I and $\mathrm{Br}$ atoms. The remaining atoms were located in suc-

Table II. Atomic positional parameters and isotropic thermal parameters $\left|\mathrm{pm}^{2} \cdot 10^{4}\right|$ for $\mathrm{TlBrI}_{2}(4-\mathrm{PicO})_{2}$.

\begin{tabular}{lllll}
\hline Atom & $x$ & $y$ & $z$ & $\mathrm{~B}_{\mathrm{eq}}$ \\
\hline $\mathrm{Tl}$ & $0.23597(9)$ & 0.250 & 0.250 & $2.40(2)$ \\
$\mathrm{I}$ & $0.1050(2)$ & $0.3492(2)$ & $0.0781(1)$ & $3.49(3)$ \\
$\mathrm{Br}$ & $0.4735(2)$ & 0.250 & 0.250 & $2.21(4)$ \\
$\mathrm{O}$ & 0.250 & 0.500 & $0.344(2)$ & $2.7(4)$ \\
$\mathrm{N}$ & 0.250 & 0.500 & $0.453(2)$ & $2.2(4)$ \\
$\mathrm{C}(1)$ & $0.343(2)$ & $0.440(3)$ & $0.510(2)$ & $3.2(4)$ \\
$\mathrm{C}(2)$ & $0.347(2)$ & $0.443(3)$ & $0.624(2)$ & $3.4(5)$ \\
$\mathrm{C}(3)$ & 0.250 & 0.500 & $0.683(3)$ & $3.7(7)$ \\
$\mathrm{C}(4)$ & 0.250 & 0.500 & $0.809(3)$ & $6(1)$ \\
\hline
\end{tabular}

Anisotropically refined atoms are given in the form of the isotropic equivalent thermal parameter, defined as:

$$
\mathrm{B}_{\mathrm{eq}}=(4 / 3)\left|a^{2} \mathrm{~B}_{11}+\ldots+a b \mathrm{~B}_{12} \cos \gamma+\ldots\right|
$$

Estimated standard deviations for the least significant figure are in parentheses. Parameters with no standard deviations were fixed by symmetry. 
ceeding difference Fourier syntheses [6]. Hydrogen atoms were not included. In the last refinement all atoms (non-H) were assigned anisotropic temperature parameters. Final refinement converged at $R=$ $0.053, R_{w}=0.063$ for 83 variables. Positional and thermal parameters are given in Table II*.

\section{Discussion}

The structure of bromo-diiodo-bis(4-methylpyridine-N-oxide)thallium(III) consists of discrete monomeric molecules in which the $\mathrm{Tl}$ atom is pentacoordinated. The molecule has a trigonal-bipyramidal structure with the halide atoms occupying equatorial positions, and the 4-picoline $\mathrm{N}$-oxide ligands in the axial positions (Fig. 1). The bond an-

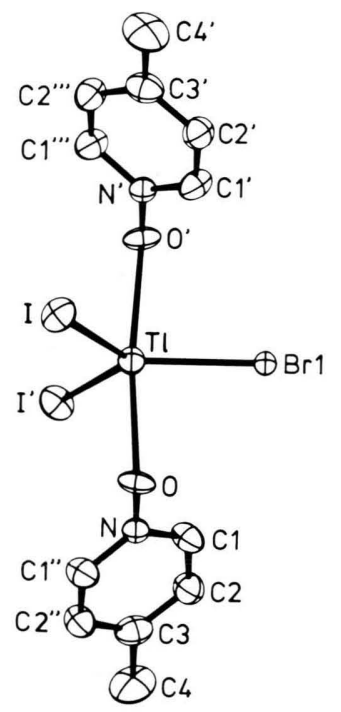

Fig. 1. The structure of $\operatorname{TlBrI}_{2}(4-\mathrm{PicO})_{2}$.
Table III. Bond lengths (pm) and angles (deg) for $\mathrm{TlBrI}_{2}(4-\mathrm{PicO})_{2}$.

\begin{tabular}{lllr}
\hline \multicolumn{3}{l}{ Bond lengths } & \multicolumn{2}{l}{ Bond angles } \\
\hline $\mathrm{Tl}-\mathrm{O}$ & $257.0(3)$ & $\mathrm{I}-\mathrm{Tl}-\mathrm{I}^{\prime}$ & $113.97(3)$ \\
$\mathrm{Tl}-\mathrm{Br}$ & $267.6(1)$ & $\mathrm{I}-\mathrm{Tl}-\mathrm{Br}$ & $123.02(2)$ \\
$\mathrm{Tl}-\mathrm{I}$ & $271.0(1)$ & $\mathrm{I}^{\prime}-\mathrm{Tl}-\mathrm{Br}$ & $123.02(2)$ \\
$\mathrm{O}-\mathrm{N}$ & $133(1)$ & $\mathrm{I}-\mathrm{Tl}-\mathrm{O}$ & $94.1(1)$ \\
$\mathrm{N}-\mathrm{C}(1)$ & $137(1)$ & $\mathrm{I}-\mathrm{Tl}-\mathrm{O}^{\prime}$ & $89.7(1)$ \\
$\mathrm{C}(1)-\mathrm{C}(2)$ & $138(1)$ & $\mathrm{Br}-\mathrm{Tl}-\mathrm{O}$ & $86.47(1)$ \\
$\mathrm{C}(2)-\mathrm{C}(3)$ & $140(1)$ & $\mathrm{Br}-\mathrm{Tl}-\mathrm{O}^{\prime}$ & $86.47(1)$ \\
$\mathrm{C}(3)-\mathrm{C}(4)$ & $152(2)$ & $\mathrm{O}-\mathrm{Tl}-\mathrm{O}^{\prime}$ & $172.95(2)$ \\
& & $\mathrm{Tl}-\mathrm{O}-\mathrm{N}^{\prime}$ & $116.3(1)$ \\
& & $\mathrm{O}-\mathrm{N}-\mathrm{C}(1)$ & $120.1(5)$ \\
& & $\mathrm{O}-\mathrm{N}-\mathrm{C}\left(1^{\prime \prime}\right)$ & $120.1(5)$ \\
& & $\mathrm{C}(1)-\mathrm{N}-\mathrm{C}\left(1^{\prime \prime}\right)$ & $119.8(9)$ \\
& & $\mathrm{N}-\mathrm{C}(1)-\mathrm{C}(2)$ & $121.1(9)$ \\
& & $\mathrm{C}(2)-\mathrm{C}(3)-\mathrm{C}\left(2^{\prime \prime}\right)$ & $119(1)$ \\
& & $\mathrm{C}(2)-\mathrm{C}(3)-\mathrm{C}(4)$ & $120.3(6)$ \\
& & $\mathrm{C}\left(2^{\prime \prime}\right)-\mathrm{C}(3)-\mathrm{C}(4)$ & $120.3(6)$ \\
\hline
\end{tabular}

gles in the equatorial plane are $113.97(3)^{\circ}$ and $123.02(2)^{\circ}$, the bond angles to the axial positions are between $86.47(1)^{\circ}$ and $94.1(1)^{\circ}$ which indicates a distorted geometry (Table III). The thallium-iodine distance is similar to those reported for triiodobis(3-methylpyridine-N-oxide)thallium [1], and the thallium bromide distance is greater than found in $\mathrm{TlBrI}_{2}\left(\mathrm{OPPh}_{3}\right)_{2}(258.0(1) \mathrm{pm})$ [4], but similar as in $\mathrm{TlBr}_{3}\left(\mathrm{C}_{5} \mathrm{H}_{5} \mathrm{~N}\right)_{3}$ [7]. The $\mathrm{Tl}-\mathrm{O}$ bond lengths $(257 \mathrm{pm})$ are longer than the expected value of $221 \mathrm{pm}$ derived from Paulings covalent radii [8].

We like to acknowledge the receipt of a research grant from DAAD (A. C. and M. E. G.-F.) and Prof. Dr. J. Strähle for providing us with facilities and his support.
[1] M. R. Bermejo, A. Castiñeiras, M. Gayoso, W. Hiller, U. Englert, and J. Strähle, Z. Naturforsch. 39b, 861 (1984).

[2] M. R. Bermejo, J. Irisarri, and M. Gayoso, Synth. React. Inorg. Met-Org. Chem., 15, 197 (1985).

[3] A. Castiñeiras, W. Hiller, M. R. Bermejo, and M. Gayoso, Acta Crystallogr. C 42, 1289 (1986).

[4] A. Castiñeiras, W. Hiller, J. Strähle, M. R. Bermejo, and M. Gayoso, An. Quím. Ser. B 82, 282 (1986).

[5] A. C. T. North, D. L. Phillips, and F. S. Mathews, Acta Crystallogr. A 24, 351 (1968).
[6] Structure Determination Package (SDP-Plus), Version 1.1 (1984) of B. A. Frenz \& Associates, Inc., College Station, Texas 77840, USA and ENRAFNONIUS, Delft, Holland.

[7] S. E. Jeffs, R. W. H. Small and I. J. Worrall, Acta Crystallogr. C40, 1827 (1984).

[8] L. Pauling: The Nature of the Chemical Bond, 3rd Edit., p. 224, University Press, Ithaca (1960). 